\author{
Asian Development Policy Review \\ $\operatorname{ISSN}(e):$ 2313-8343 \\ $\operatorname{ISSN}(p): 2518-2544$ \\ DOI: $10.18488 / 5008 . v 10 i 1.4397$ \\ Vol. 10, No. 1, 1-15. \\ (C) 2022 AESS Publications. All Rights Reserved. \\ URL: www.aessweb.com
}

\title{
THE IMPACT OF INCOME ON THE DIVISION IN DOMESTIC LABOR: THE CASE STUDY IN RURAL VIETNAM
}

\section{(i) Phuong Nu Minh Le}

\author{
University of Economics, Hue University, Vietnam. \\ Email:lenuminhphuong@hueuni.edu.vnTel: +84.944877759
}

Article History

Received: 14 October 2021 Revised: 23 November 2021 Accepted: 8 December 2021 Published: 12 January 2022

\section{Keywords}

Income

Gender

Division

Domestic labor

Exchange theory

Vietnam.

JEL Classification: D31, J16, O18.

\begin{abstract}
The imbalance in the distribution of responsibilities for unpaid work has profoundly affected women's' empowerment and full participation in economic and social activities. The study surveyed more than 150 households in one rural area in one Vietnamese province. This study's result in the central rural area did not improve Vietnamese domestic labor division compared to previous studies. The daily time taken up doing housework strongly correlates with gender, and the t-Test is statistically significant differences in the mean by gender. Wives earn additional money, and then spend less time on housework; nonetheless, the wife's minimum threshold for housework time is much higher than her husband's maximum threshold. Unlike the time devoted to housework, how much income contributes to the household does not affect childcare time. Except for the gender factor, the importance and extent of factors affecting housework and childcare differed markedly. Peculiarly, the unemployment of husbands is not a normal situation in Vietnamese families, so the assumption of exchange theory is not satisfied, though the wife is almost unable to negotiate with the unemployed husband.
\end{abstract}

Contribution/ Originality: This is the first study to evaluate the impact of income on the division in household chores in Vietnam, combining three methods of the chart, the t-Test, and OLS. This study contributes to the empirical evidence where exchange theory does not apply and can only be explained by gender.

\section{INTRODUCTION}

The definition of 'family' has been changing, so has the role of each individual in the family. A mother's traditional role is as a housewife and child carer, and that of a father is as a breadwinner, which has been gradually changing. When women enter the labor market, the father's role in the family also gradually changes. Many theories approach the family and social trends, such as structural-functional theories, conflict theories, exchange theory, life-course theory, feminist theories, and social and cultural capital theories. This study applies the exchange theory because it is based on the principles of economic theory to explain the relational behaviors in the family such as marriage, divorce, childbirth, housework, and dependent care. According to exchange theory, the person with more resources holds more power and, ultimately, is in a better position to benefit from the exchange. Income is considered the central factor showing the bargaining power in the exchange between housework and the incomes of the husband and wife (Bittman, England, Sayer, Folbre, \& Matheson, 2003; Killewald \& Gough, 2010). Exchange theory also includes other concepts used to describe the characteristics of social interactions. Research needs to explore this threshold of income-adjusted housework time to sustain a family based on social norms and exchange theory. The process of growth and economic development is always accompanied by income disparities. 
Income inequality by gender is a problem that has been studied in many countries. With the increasing number of women participating in the labor market in recent decades, the proportion of housework done by women compared to men is decreasing, but women still do of most of the housework (Coltrane, 2000; Kan, Sullivan, \& Gershuny, 2011; Killewald \& Gough, 2010). Vietnam has about 19.4 million laborers working in the agricultural sector, accounting for 34.7 percent of the total labor force in 2019 (GSO, 2019). Vietnamese women have made much progress compared to men on some labor market measures. Up to 76 percent of adult women (15 to 64 years old) are working compared to 49.6 percent globally and 61.1 percent in Southeast Asia and the Pacific (Cunningham, Alidadi, \& Buchhave, 2018). Vietnamese women's participation in the labor force is much higher than other countries in Southeast Asia and the Pacific that have a, similar development level to Vietnam (Cunningham et al., 2018). The Vietnamese Gender Inequality Index (GII) is at 0.314, ranking it 68 of 162 countries in 2018, compared with the Philippines, Thailand, China, and Malaysia that are ranked at 98, 84, 39, and 58, respectively (UNDP, 2019). The previous research on gender inequality in Vietnam includes (1) an overview of gender in Vietnam (Lynellyn, Le, Allison, Le, \& Nguyen, 2000; Moghadam, 1995; World Bank, 2006, 2011) (2) different family modes between regions (Bélanger, 1998) (3) impact of employment on gender inequality (Nguyen, Van den Berg, \& Lensink, 2011) (4) division of domestic labor in Vietnam (Teerawichitchainan, Knodel, Loi, \& Huy, 2010) and (5) the role of women in economics and families (Truong, Giao, Ly, \& Giang, 2020). However, there is no study primarily on the effect of income on domestic chores assignments. Based on exchange theory, women with little or no resources, especially peasant women, suffer from many injustices in family labor division (Agarwal, 1997; Teerawichitchainan et al., 2010). Many studies have focused only on the relationship between housework and income (Bianchi, Milkie, Sayer, \& Robinson, 2000; Bittman et al., 2003; Hersch \& Stratton, 1994; Killewald \& Gough, 2010; Makiko \& Philip, 2007) and very few studies have paid attention to the relationship between income and both housework and childcare. The article focuses on the study in the rural areas on inequality in household labor division and income. The purpose of the study is (i) to test the difference between the division of labor between husband and wife, (ii) to analyze whether or not income has an impact of on housework and childcare assignment, (iii) to analyze the factors affecting the time of housework and childcare, (iv) to gather evidence to propose solutions that will reduce inequality in the family and society.

\section{LITERATURE REVIEW}

\subsection{Foreign Literature Review}

Economic-based exchange theory has made remarkable achievements in family research. There are three basic assumptions of exchange theory. First, each interaction is represented by an exchange of resources. Second, individuals are rational and future-oriented, who weigh benefits and costs before acting Third, individuals choose to retain in their exchange the most happiness. Accepting the three assumptions above, the exchange provides an incentive for each person. Spouses interact because they need things like love, money, help, comfort, and other things from spouses, and the interaction is motivated by the desire to achieve happiness.

Exchange theory provides an analytical framework for reducing gender inequality through (1) formal institutions, (2) markets, (3) households and (4) informal institutions. The socio-economic environment and human life viewpoints are gradually changing, such as the declining fertility rate and the gender disparity in education, employment rate, and occupational income level that all affect gender inequality (Ammons \& Kelly, 2015). Simultaneously, differences in culture, markets, formal and informal institutions affect the division of time by gender (Conceição, 2019). For example, Japanese women do more housework than Chinese, South Korean, or Taiwanese women, and Japanese men do exceptionally little housework (Kan, Hertog, \& Kolpashnikova, 2019).

The gender division of labor in terms of the family has a statistical difference by gender; discrimination by gender is still apparent (Baxter, 2002). In a few other studies in countries with high gender equality and under some specific conditions, gender does not affect housework time (Evertsson, 2014; Kan \& Laurie, 2018). According 
to the Quebec Time Survey in 2001, fathers spend more time with their families than they did in the survey in 1998 (St-Amour, Laverdure, Devault, Manseau, \& Jacob, 2007). However, wives still do more housework (56 percent of tasks for dual-earner couples and having one child under five years old) and take more care of family members (61 percent) (St-Amour et al., 2007). Coltrane (2000) and St-Amour et al. (2007) also conclude that women have been adjusting to reduce housework time, although women still do most household chores. In a gender-equal country like Sweden, women socialized in equal-sharing households are inclined to share housework equally with their partners (Ruppanner, Bernhardt, \& Brandén, 2017). Women have increasing choices to reduce the time spent on housework for two main reasons (i) the service market has increasingly been providing available services to support women to take care of children and housework; (ii) women have more and more opportunities to obtain full-time or part-time jobs. On the other hand, the changing roles of spouses in the family is also classified by two groups of factors: (i) inclusive-couple factors: the personal availability of the spouse, the relationship between spouses, economic resources, gender ideology, education, age, ethnicity, and social class; and (ii) exclusive-couple factors: the social welfare system, gender norms, women's participation in the labor market and economic development (Bouffartigue, 2010; Makiko \& Philip, 2007).

The exchange theory says that the husband or the wife with a relatively higher income will have the right to order the spouse to do more household chores. Van der Lippe, Treas, and Norbutas (2018); Teerawichitchainan et al. (2010) conclude that it is reasonable to make up for the gap in the contribution of household income by spending more time on family care. However, the exchange level between income and time spent on household chores differs between husband and wife. Bittman et al. (2003) and Van der Lippe et al. (2018) indicate no balance tradeoff between income and housework; in addition, gender ideology is still more dominant than money. Men in the United States adjust a slight increase in household chores as their wives contribute more to the family income (Bianchi et al., 2000). Unlike the United States, the amount of housework that Australian men do is not affected by their wife's earnings, contrary to the exchange theory (Bittman et al., 2003). The unemployed husband is reluctant to undertake domestic labor, so the employed wife is even more stressed by the burden of having to do two tasks at a time (Bianchi et al., 2000; Gough \& Killewald, 2011; Van der Lippe et al., 2018).

\subsection{Vietnamese Literature Review}

The market economy has revived the Vietnamese economy and created many economic opportunities (Dollar, Glewwe, \& Litvack, 1998), therefore, presumably reducing gender inequality. New economic opportunities promote economic restructuring, shift labor from rural to urban areas, and create more jobs. According to the GSO \& UNFPA (2005) for every 100 female migrants, there are only 76 male migrants, and women make up most of the young migrants (SUR, 2016). Comparing data from the 2004 and 2015 migration surveys in Vietnam, the gap between migrants and non-migrants living conditions between two periods has reduced from 18.8 percent to 5.2 percent (SUR, 2016). Additionally, Actionaid (2008) it also confirmed that Vietnamese women are becoming more and more independent in the community, such as borrowing money and managing the family more effectively when their husbands are away from or unable to work. Vice versa, if the wife works away from home, the husband takes on housework. New economic opportunities promote husband/wife roles in the family and improve gender inequality in housework and childcare sharing. Furthermore, Nguyen et al. (2011) concluded that both working and non-working migration also mitigate inequality. However, this progress is non-linear and does not necessarily narrow the gender gap (Teerawichitchainan et al., 2010). Research on gender inequality includes income inequality in the workplace (Cunningham et al., 2018) disparities in wages (Teerawichitchainan et al., 2010), job subgroups by gender and specifically gender-based agriculture (Quyen, Nguyen, Nguyen, Nguyen, \& Do, 2006) inequality in educational attainment by gender (Desai, 2000), household chores division (Institute for Social Development Studies, 2015) etc., and mainly use descriptive statistical methods. Household chores still belong to women, but the gender-differentiated household chores have decreased because of the high proportion of women participating in 
the labor market. According to a survey by Desai (2000) each household spends 4-5 hours a day on household chores, and on average, women contribute 70 percent of their time to household chores. The research of Actionaid (2008) concludes that women, on average, spend five hours on household chores compared to three hours for men. Ethnic minority women have to do housework without pay up to nine hours a day compared to five hours for Kinh women (Cunningham et al., 2018). Women undertake 12 out of 14 listed tasks related to cooking, caring for elderly and sick people, while men undertake two main tasks: maintenance, repair, and family representatives working with authorities (Institute for Social Development Studies, 2015). Women in rural areas, specifically in Nghia Hiep commune, spend time on farming and livestock, and an average 3.7 hours/day on housework, with the highest up to 7 hours/day, and the lowest 1 hour/day for housework (Quyen et al., 2006).

Income is more comprehensive than the wage gap because wages only reflect differences at the payer/wage unit. Wage gaps persist due to occupational divisions, the burden of unpaid care work, discrimination against women in the workplace, and labor legislation restricting female laborers' careers choice (Cunningham et al., 2018). Market reform has created various economic opportunities (Dollar et al., 1998) whereby the gender income gap in Vietnam declined rapidly after the reform (Teerawichitchainan et al., 2010). The gender income gap in Vietnam has been adjusting downward from 22 percent in 1998 to 15 percent in 2002 (Teerawichitchainan et al., 2010). The gender pay gap has gradually reduced from $14 \%$ in the study of Institute for Social Development Studies (2015) to $10 \%$ in the study of Cunningham et al., (2018). Between 2007 and 2014, the salary difference between men and women narrowed from 15.4 percent to 12.6 percent (Demombynes \& Testaverde, 2018). The average income of Vietnamese women is equal to 85.6 percent of that of men; also, this figure is higher than that of middle-income countries like the Philippines (65.5 percent), Thailand (79.4 percent), and especially surpasses the global average (29.3 percent) (Conceição, 2019). No studies have been found to analyze the impact of income on the division in household chores by husband and wife in Vietnam.

\section{RESEARCH METHODOLOGY}

\subsection{Survey Methodology}

Primary data is obtained through a direct interview conducted in Phu Vang district in 2019. The complex sample design is divided into two phases and stratified in the household survey sample. The first phase is to determine which communes should be surveyed based on the study area's geographical characteristics. Phu Vang has 18 communes and two townships, of which 18 communes feature three geographical regions characterized by coastal sandy, lagoon, and delta. Therefore, simple random samples were selected from 3 out of 18 communes in Phu Vang district: Phu Mau commune (delta area), Phu Xuan commune (lagoon area), Phu Thuan commune (coastal area). The second phase involves choosing households from three communes. The goal of the study is to survey working-age households basing on the household list of each commune. So, fifty households in each commune are randomly surveyed. The content of the questionnaire focused on (i) elementary household information, (ii) time allocation for domestic labor for wife and husband, (iii) employment situation and income of each household member.

\subsection{Analytical Approach}

Most studies on gender use descriptive statistics and OLS methods; a few studies use other methods such as logistic regression, random intercept regression, and fixed effect model, as shown in Table 1. The study conducted a step-by-step analysis to test whether income does or does not affect household chores by spouses (i) testing differences in housework, childcare, and income by the spouse, and (ii) determining the impact of income on household chores and childcare. The research applies in succession (i) two-samples t-Test to check the difference in the mean between husband and wife following some criterion, (ii) a graph to see the visual differences in income 
and the relationship between household chores and income and (iii) OLS regression model. The following onetailed t-Test hypotheses were proposed:

\section{$H_{0}: \mu_{\mathrm{t}-\text { husband }}=\mu_{\mathrm{t}-\mathrm{wife}}$ : the time means of $t$ (housework/childcare) for husband and wife are the same.}

$H_{1}: \mu_{\mathrm{t}-\mathrm{wife}}>\mu_{\mathrm{t}-\text {-husband }}$ the time means oft (housework/childcare) for the wife are longer than those of the husband.

Table 1. Variable definitions and empirical literature.

\begin{tabular}{|c|c|c|c|c|}
\hline Name & Variable definitions & Authors/calculation & Method & Findings \\
\hline \multirow[t]{2}{*}{ Housework } & \multirow{2}{*}{$\begin{array}{l}\text { Hours per day spent on } \\
\text { cooking, } \\
\text { markets, shopping, and } \\
\text { other non-routine tasks }\end{array}$} & $\begin{array}{l}\text { Geist and Cohen } \\
(2011) \\
\text { Housework score }\end{array}$ & $\begin{array}{l}\text { Random } \\
\text { intercept and } \\
\text { random slope } \\
\text { models }\end{array}$ & $\begin{array}{l}\text { In the egalitarian countries, equal division of } \\
\text { labor in } 2002 \text { is better than in } 1994 . \\
\text { In the countries with conservative welfare, } \\
\text { there is almost no change in the domestic } \\
\text { division of labor }\end{array}$ \\
\hline & & $\begin{array}{l}\text { Bianchi et al. (2000) } \\
\text { Listed housework task }\end{array}$ & $\begin{array}{l}\text { Descriptive } \\
\text { analysis } \\
\text { OLS }\end{array}$ & $\begin{array}{l}\text { American women have reduced } 12 \\
\text { hours/week since } 1960 \text {. } \\
\text { Unemployed husbands do less domestic labor } \\
\text { than employed husbands }\end{array}$ \\
\hline Childcare & $\begin{array}{l}\text { Hours per day spent on } \\
\text { childcare }\end{array}$ & $\begin{array}{l}\text { Evertsson (2014) } \\
\text { Childcare in an hour } \\
\text { per week }\end{array}$ & $\begin{array}{l}\text { Descriptive } \\
\text { analysis } \\
\text { OLS }\end{array}$ & $\begin{array}{l}\text { Couples with solid egalitarianism, both } \\
\text { husband and the wife have an equal division } \\
\text { of childcare }\end{array}$ \\
\hline \multirow{2}{*}{$\begin{array}{l}\text { Child } \\
\text { characteristics } \\
(\mathrm{CC})\end{array}$} & \multirow{2}{*}{$\begin{array}{l}\text { O: no children; } 1: \text { child } \\
<15 \text { years old; } 2: 2 \text { child } \\
\text { or more }<15 \text { years old; } \\
\text { 3: } 1 \text { child } \geq 15 \text { years } \\
\text { old; } 4: 2 \text { child or more } \\
\geq 15 \text { years ol }\end{array}$} & $\begin{array}{l}\text { Bianchi et al. (2000) } \\
\text { Categorical variable }\end{array}$ & $\begin{array}{l}\text { Descriptive } \\
\text { analysis } \\
\text { OLS }\end{array}$ & $\begin{array}{l}(+) \text { housework } \\
(+) \text { childcare }\end{array}$ \\
\hline & & $\begin{array}{l}\text { Hersch and Stratton } \\
(1994) \\
\text { Categorical variable } \\
\end{array}$ & $\begin{array}{l}\text { Descriptive } \\
\text { analysis } \\
\text { OLS }\end{array}$ & $\begin{array}{l}\text { Couples having a child under } 12 \text { years old } \\
\text { devoted additional time for housework }\end{array}$ \\
\hline \multirow{2}{*}{ Age } & \multirow{2}{*}{ Age in year } & $\begin{array}{l}\text { Hersch and Stratton } \\
(1994)\end{array}$ & $\begin{array}{l}\text { Descriptive } \\
\text { analysis } \\
\text { OLS }\end{array}$ & $\begin{array}{l}\text { Young wives tend to do less housework than } \\
\text { older wives }\end{array}$ \\
\hline & & $\begin{array}{l}\text { Bianchi et al. (2000) } \\
\text { Categorical variable }\end{array}$ & $\begin{array}{l}\text { Descriptive } \\
\text { analysis } \\
\text { OLS }\end{array}$ & $\begin{array}{l}\text { Men aged } 55 \text { to } 64 \text { and women aged } 35 \text { or } \\
\text { older do more housework than young people }\end{array}$ \\
\hline \multirow{5}{*}{$\begin{array}{l}\text { Income per } \\
\text { month (IC) }\end{array}$} & \multirow{5}{*}{$\begin{array}{l}\mathrm{O}: \quad \mathrm{IC}=0 ; \quad 1: \quad 0<\mathrm{IC} \leq 3^{*} \\
2: 3<\mathrm{IC} \leq 5^{*} ; 3: 5<\mathrm{IC} \leq 7^{*} \\
4: \mathrm{IC}>7^{*}\end{array}$} & $\begin{array}{l}\text { Baxter (2018) } \\
\text { Weekly income }\end{array}$ & $\begin{array}{l}\text { Descriptive } \\
\text { analysis }\end{array}$ & $\begin{array}{l}\text { Wife earns more than reduce housework } \\
\text { time until equal division domestic labor } \\
\end{array}$ \\
\hline & & Bittman et al. (2003) & OLS & $\begin{array}{l}\text { American women earn more money and do } \\
\text { less housework. }\end{array}$ \\
\hline & & $\begin{array}{l}\text { Bittman et al. (2003); } \\
\text { Brown and Roberts } \\
(2014)\end{array}$ & OLS & $\begin{array}{l}\text { Australian women earn more than their } \\
\text { husbands; they increase the amount of } \\
\text { housework they do }\end{array}$ \\
\hline & & $\begin{array}{l}\text { Killewald and Gough } \\
(2010)\end{array}$ & $\begin{array}{l}\text { OLS, Fixed } \\
\text { effects model }\end{array}$ & $\begin{array}{l}\text { Husbands whose wives work out of the } \\
\text { family devote additional time to housework. } \\
\text { The relationship between wives' earnings } \\
\text { and their housework time is non-linear. }\end{array}$ \\
\hline & & $\begin{array}{l}\text { Hersch and Stratton } \\
(1994)\end{array}$ & $\begin{array}{l}\text { Descriptive } \\
\text { analysis } \\
\text { OLS }\end{array}$ & $\begin{array}{l}\text { Housework time spent by spouses is } \\
\text { inversely related to their income. }\end{array}$ \\
\hline \multirow[t]{2}{*}{$\begin{array}{l}\text { Income share } \\
\text { (IS) }\end{array}$} & \multirow{2}{*}{$\begin{array}{l}0: \mathrm{IS}=0 \\
1: 0<\mathrm{IS} \leq 0.3 \\
2: 0.3<\mathrm{IS} \leq 0.5 \\
3: 0.5<\mathrm{IS} \leq 0.7 \\
4: 0.7<\mathrm{IS} \leq 1.0\end{array}$} & $\begin{array}{l}\text { James } \quad \text { and } \\
\text { Warner }(2015)\end{array}$ & $\begin{array}{l}\text { Descriptive } \\
\text { analysis, } \\
\text { Logistic } \\
\text { Regression }\end{array}$ & (-) housework \\
\hline & & Bittman et al. (2003) & OLS & $\begin{array}{l}\text { Husband's IS increases do not affect the } \\
\text { husband's household labor time, and the wife } \\
\text { is inverse. }\end{array}$ \\
\hline $\begin{array}{l}\text { Household size } \\
(\mathrm{HZ})\end{array}$ & Household size & $\begin{array}{l}\text { Geist and } \\
(2011)\end{array}$ & $\begin{array}{l}\text { Random } \\
\text { Intercept } \\
\text { Regression }\end{array}$ & $\begin{array}{l}\text { The larger the household size, the less time } \\
\text { couple does housework }\end{array}$ \\
\hline
\end{tabular}

Note: * million VND; 1USD=23,075VND

\subsection{Variable Definition}

Geist and Cohen (2011) only focus on routine household chores and solve the gender equality issues. To overcome the disadvantages of Geist and Cohen (2011), James and Clay-Warner (2015) measure the domestic 
labor of each spouse in a week. This study did not measure housework and childcare by week but measured the number of hours spouses spent on housework and childcare each day. Some non-daily tasks are surveyed weekly and then averaged over the number of hours a day for housework/childcare. The study uses two income-related measurement tools: income and household income share (relative proportion of spouses' income versus gross family income) (Table 1). The spouse's income variable is a continuous variable, calculated in a million VND (equivalent to the exchange rate of $1 \mathrm{USD}=23075 \mathrm{VND}$ at the survey time).

The study used age, children's' characteristics and household size to analyze the impact on the husband's and wife's time allocation for family activities. Young wives tend to do less housework than older wives, partly because they are inclined to discuss with their husbands and divide the housework more fairly than older wives (Hersch \& Stratton, 1994). Like James and Clay-Warner (2015) and Baxter. (2018) this research applies age in the form of a continuous variable. The research did not employ dummy variables like those used by Hersch and Stratton (1994) and Brown and Roberts (2014) to specify the children specifications of each couple, but rather a categorical variable with five subgroups: 0 - no child, 1 - one child aged less than 15 years; 2 - two children or more than two children aged less than 15 years; 3 - one child aged greater than or equal to 15 years, 4 - two children or more than two children aged greater than or equal to 15 years (Table 1). There are two reasons behind the specification: (1) the fertility rate in rural areas is 2.26 children per woman (GSO, 2019) (2) children aged 15 or above are capable of doing substantial housework. A feature of Asian families, especially in rural areas, is that married children often live with their parents or in a three-generation family. The paper included the "child characteristics" variable in the study and added the variable "household size" to analyze the impact on housework and childcare.

\section{A GAP IN THE DIVISION OF HOUSEHOLD CHORES AND INCOME BY GENDER}

\subsection{Assigning Household Chores According to Husband and Wife}

Table 2 revealed significant and statistical differences in the time of housework/childcare, indicating that $\mathrm{H}_{1}$ was accepted. The difference in the average value of time between husband and wife for housework (2.62 hours) and childcare (0.68 hours) the burden of which falls primarily on the wife's shoulders. This finding is compatible with previous studies on the gender of Baxter (2002); Coltrane (2000). Vietnamese rural wife's time spent in household chores (up to 83 percent of the total amount of domestic labor) has not decreased, compared with previous Vietnamese studies such as Quyen et al. (2006); Actionaid (2008) and Teerawichitchainan et al. (2010) closely approximate the average in the study of Lynellyn et al. (2000) and Desai (2000) 20 years ago. Women undertake up to 83 percent of the housework, which is higher than the average time of women in Kan and Laurie (2018) of 70 percent, Baxter (2002) of 75 percent and which is close to that of Pakistani women (Kan \& Laurie, 2018).

Table 2. T-test about mean time per day spent on housework and childcare, by spouses.

\begin{tabular}{l|c|c|c|c}
\hline \multirow{2}{*}{ Items } & \multicolumn{2}{|c|}{ Housework } & \multicolumn{2}{c}{ Childcare } \\
\cline { 2 - 5 } & Wife & Husband & Wife & Husband \\
\hline No. & 159 & 152 & 159 & 152 \\
\hline Mean (hour) & 3.28 & 0.66 & 1.88 & 1.20 \\
\hline Diff=mean(wife)-mean(husband) & \multicolumn{2}{|c|}{2.62} & \multicolumn{2}{c}{0.68} \\
\hline Sig & \multicolumn{2}{|c}{$0.00<0.05$} & \multicolumn{2}{c}{$0.00<0.05$} \\
\hline Conclusion & \multicolumn{2}{|c|}{$\begin{array}{c}\text { The statistically significant difference in the mean of time } \\
\text { for household chores between wife and husband groups }\end{array}$} \\
\hline
\end{tabular}

Unlike housework, the time taking care of children is only 0.68 hours/day in disparity; either the wife spends 61 percent of the total time for childcare (Table 2). Vietnamese fathers taking care of their children are slightly higher (about 7 percent) than Australian fathers in Baxter (2002). The wife does daily feeding, bathing, and teaching tasks as the husband saves time to talk, teach, and take the children out. 
Table 3. T-test about mean time per day for housework and childcare, by husband/wife, and by child characteristics

\begin{tabular}{|c|c|c|c|c|c|c|c|c|c|c|}
\hline \multirow[t]{2}{*}{ Items } & \multicolumn{2}{|c|}{ No child } & \multicolumn{2}{|c|}{$\begin{array}{l}\text { one child }<15 \\
\text { years }\end{array}$} & \multicolumn{2}{|c|}{$\begin{array}{l}\text { two children or } \\
\text { more }<15 \text { years }\end{array}$} & \multicolumn{2}{|c|}{$\begin{array}{l}\text { one child } \geq 15 \\
\text { years }\end{array}$} & \multicolumn{2}{|c|}{$\begin{array}{l}\text { two children or } \\
\text { more } \geq 15 \text { years }\end{array}$} \\
\hline & Wife & Husband & Wife & Husband & Wife & Husband & Wife & Husband & Wife & Husband \\
\hline No. & 3 & 3 & 10 & 9 & 53 & 53 & 37 & 34 & 46 & 46 \\
\hline \multicolumn{11}{|l|}{ Housework } \\
\hline Mean (hours) & 2.33 & $\mathrm{O}$ & 3.33 & 0.89 & 3.51 & 0.89 & 3.35 & 0.54 & 3.11 & 0.57 \\
\hline $\begin{array}{l}\text { Diff }=\text { mean(wife)- } \\
\text { mean(husband) }\end{array}$ & \multicolumn{2}{|c|}{2.33} & \multicolumn{2}{|r|}{2.41} & \multicolumn{2}{|r|}{2.62} & \multicolumn{2}{|r|}{2.81} & \multicolumn{2}{|r|}{2.54} \\
\hline Sig & \multicolumn{2}{|c|}{$0.00<0.05$} & \multicolumn{2}{|c|}{$0.00<0.05$} & \multicolumn{2}{|c|}{$0.00<0.05$} & \multicolumn{2}{|c|}{$0.00<0.05$} & \multicolumn{2}{|c|}{$0.00<0.05$} \\
\hline Conclusion & \multicolumn{10}{|c|}{$\begin{array}{l}\text { The statistically significant difference in mean between wife and husband groups, by all child } \\
\text { specifications }\end{array}$} \\
\hline \multicolumn{11}{|l|}{ Childcare } \\
\hline \multicolumn{3}{|l|}{ Mean (hours) } & 2.0 & 1.44 & 2.25 & 1.46 & 1.84 & 1.17 & 1.83 & 1.11 \\
\hline \multicolumn{3}{|c|}{ Diff $=$ mean(vợ)-mean(chồng) } & \multicolumn{2}{|r|}{0.56} & \multicolumn{2}{|r|}{0.78} & \multicolumn{2}{|r|}{0.66} & \multicolumn{2}{|r|}{0.71} \\
\hline \multicolumn{3}{|l|}{ Sig } & \multicolumn{2}{|c|}{$0.14>0.10$} & \multicolumn{2}{|c|}{$0.00<0.05$} & \multicolumn{2}{|c|}{$0.00<0.05$} & \multicolumn{2}{|c|}{$0.00<0.05$} \\
\hline \multicolumn{3}{|l|}{ Conclusion } & \multicolumn{2}{|c|}{$\begin{array}{l}\text { Non-significant } \\
\text { difference }\end{array}$} & \multicolumn{6}{|c|}{$\begin{array}{l}\text { The statistically significant difference in mean } \\
\text { between wife and husband for groups more than one } \\
\text { child or one child older than } 15\end{array}$} \\
\hline
\end{tabular}

The results in Table 3 confirm that, despite the differences in the children's characteristics, hours in housework still have a sharp distinction between husband and wife and are statistically significant. The gap in the of share in housework time between wife and husband increase while having children (Hersch \& Stratton, 1994) the increment of this gap from 2.33 hours/day to 2.81 hours/day when child characteristics change from: no child; one child; two or more than two children under 15 years old; to one child equal or older than 15 years old. The wife having two or more than two children older than 15 years is shared housework by other family members, so the number of housework hours decreases slightly (averaged at 2.54 hours). This finding is partly in line with these studies of Shelton and John (1993) and Hersch and Stratton (1994) that older women are more inclined to undertake more household chores. Only three households in the sample size of 149 households were without children, which may surprise Western researchers, but this makes sense for Asian cultures because married couples frequently do not delay having children. Especially for couples without children, the husband scarcely does any housework. The children's characteristics changing from no child to having a child motivated the father to share housework with his wife, similar to Killewald and Gough (2010) but contrary to Gjerdingen and Center (2005). However, the couple had one child or more than one child equal to or older than 15 years, whose husband has downward adjusted the average hours to just over 0.5 hours (Table 3), which is consistent with Evertsson (2014). Subsequently, despite the distinction in children's characteristics, the husband's share of housework is still minor, and the wife undertakes more than 80 percent of the housework.

Unlike housework time, the mean of childcare time between husband and wife is as much as statistically significant for all child characteristics, except for a household with the first child (Table 3). Only couples with their first child have the lowest childcare time distinct (0.56 hours) and are not statistically significant, which means accept $\mathrm{H}_{0}$. The first experience of being a father and a mother makes them feel incredibly unaccustomed, tense, and unfamiliar with raising children and developing relationships with the third family member. The couple's daily lifestyle no longer exists; it undergoes a period of exchange, discussion, conflict, and compromise to set each family member's limited scope. However, the statistically significant difference no longer appears when couples have two or more children or one child aged equal to or greater than 15 years. It seems that the father prefers to concede to the wife in child-raising by idealizing their motherhood, so the father justifies that the reduction in childcare is reasonable. On the other hand, as children grow up, they can take care of their personal needs without much support from their parents. 


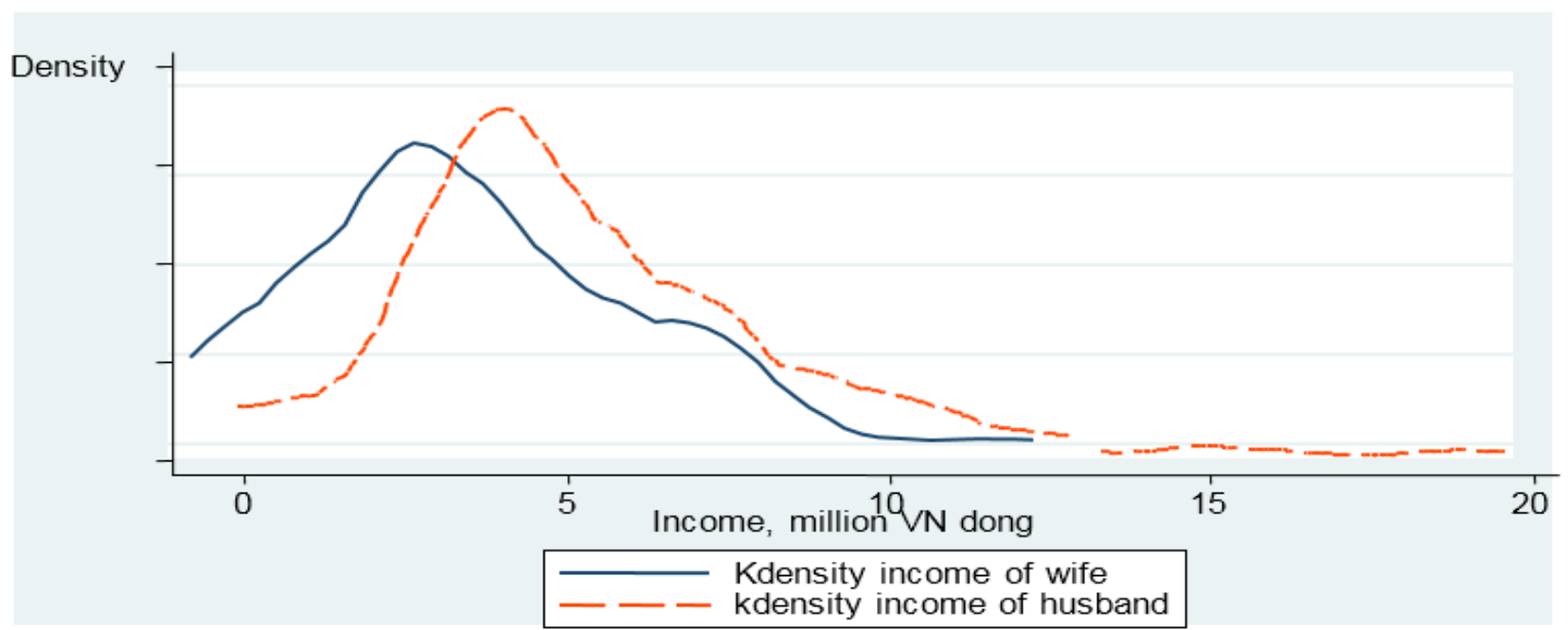

Figure 1. Density estimation of income by wife/husband.

The wife's average income is lower than the husband's; the husband-wife income disparity is VND1.88 million, as shown clearly in Figure 1 and Table 4. In general, the average income of surveyed labor is less than VND5 million/month (VND4.77 million/month) (Table 4). First, the overall unemployment rate is 9 percent, of which the wife and the husband's unemployment rates are 13.21 percent and 4.61 percent, respectively. The unemployment rate in this rural area is exceptionally high compared to the overall unemployment rate of Vietnam in 2019 at 2.04 percent (Statista, 2021), partly due to the following reasons: (1) production of self-sustaining agriculture rather than cash earning (2) a large proportion of women are responsible for household chores. Furthermore, up to 49.69 percent of the wife's income is equal to or less than VND3 million, whereas only 17.77 percent of the husband's income is at that income level. 10.69 percent of wives' incomes are above VND7 million, the number of husbands achieving that income is 20.39 percent. In summary, the wife's income in the surveyed rural area is only 63.95 percent of her husband's income, lower than the 69 percent reported by the Asian Development Bank in 2002 survey of Vietnamese women (Teerawichitchainan et al., 2010). The income wifehusband gap is 2-3 times larger than the income labor female-male gap in general in the study of Institute for Social Development Studies (2015) and Cunningham et al. (2018).

Table 4. The income and income share by wife/husband

\begin{tabular}{|c|c|c|c|c|c|c|c|c|c|c|}
\hline \multirow{2}{*}{ Group } & \multicolumn{5}{|c|}{ Income } & \multicolumn{5}{|c|}{ Income share } \\
\hline & $\mathbf{0}$ & $0<\mathrm{IC} \leq 3^{*}$ & $3<\mathrm{IC} \leq 5^{*}$ & $5<\mathrm{IC} \leq 7$ * & $\mathrm{IC}>7^{*}$ & $\mathbf{I S}=\mathbf{0}$ & $0<\mathrm{IS} \leq \mathbf{0 . 3}$ & $0.3<\mathrm{IS} \leq 0.5$ & $0.5<\mathrm{IS} \leq 0.7$ & $0.7<\mathrm{IS} \leq 1.0$ \\
\hline \multicolumn{11}{|c|}{ Wife $(n=159 ; \mathrm{IC}=3.69$ million $\mathrm{VND}, \mathrm{IS}=40 \%)$} \\
\hline $\begin{array}{c}\text { Mean } \\
\text { (IC) }\end{array}$ & $\mathrm{O}$ & 2.29 & 4.20 & 6.19 & 8.26 & $\mathrm{O}$ & 2.57 & 4.51 & 5.69 & 3.3 \\
\hline Freq. & 21 & 58 & 39 & 24 & 17 & 21 & 19 & 87 & 15 & 17 \\
\hline$\%$ & 13.21 & 36.48 & 24.53 & 15.09 & 10.69 & 13.21 & 11.9 & 54.72 & 9.43 & 10.69 \\
\hline \multicolumn{11}{|c|}{ Husband $(\mathrm{n}=152 ; \mathrm{IC}=5.57$ million VND, $\mathrm{IS}=60 \%)$} \\
\hline $\begin{array}{c}\text { Mean } \\
\text { (IC) }\end{array}$ & $\mathrm{O}$ & 2.62 & 4.29 & 6.45 & 10.34 & $\mathrm{O}$ & 1.71 & 5.07 & 6.20 & 5.79 \\
\hline Freq. & 7 & 20 & 62 & 32 & 31 & 7 & 2 & 24 & 79 & 40 \\
\hline$\%$ & 4.61 & 13.16 & 40.79 & 21.05 & 20.39 & 4.61 & 1.32 & 15.79 & 51.97 & 26.32 \\
\hline \multicolumn{11}{|c|}{ Wife + Husband $(\mathrm{n}=311 ; \mathrm{IC}=4.77$ million VND) } \\
\hline $\begin{array}{c}\text { Mean } \\
\text { (IC) }\end{array}$ & $\mathrm{O}$ & 2.37 & 4.26 & 6.34 & 9.61 & $\mathrm{O}$ & 2.49 & 4.63 & 6.11 & 5.10 \\
\hline Freq. & 28 & 78 & 101 & 56 & 48 & 28 & 21 & 111 & 94 & 57 \\
\hline$\%$ & 9.00 & 25.08 & 32.48 & 18.01 & 15.43 & 9.00 & 6.75 & 35.69 & 30.23 & 18.33 \\
\hline
\end{tabular}


Along with altering the IS groups, most of the husbands in the surveyed area are breadwinners, and over 78 percent of husband have more IC than their wife. So, the husband's average income is higher than the wife's at all IS groups. However, the average income of the group (IS $>0.7)$ is lower than one of the groups $(0.5<\mathrm{IS} \leq 0.7)$ (Table 4$)$. That is why both husband and wife, together with the same ability to earn money, will promote and support each other in their jobs to raise income. In particular, the wife who contributes more than 0.7 of household income has an average income of only VND3.3 million because 17 women who contribute more than 0.7 of household income are in the status of divorced or widowed or unemployed-husbands' wives. The proportion of women in divorced and widowed is 2-7 times higher than that of men (Institute for Social Development Studies, 2015) which is consistent with the findings of this study.

\section{IMPACT OF INCOME ON HOUSEHOLD LABOR DIVISION}

\subsection{Examining the Relationship between Income and the Amount of Time Spent On Domestic Labor by a Graph}

Before examining the relationship between income and household duties, the study uses Figure 2 to shape this relationship. Figure 2 illustrates that in common, the greater the earnings, the less time-consuming household chores. However, a part of the predicted line (Figure 2-Husband) does not reflect this relationship, explaining why some of the husbands are unemployed and simultaneously do not do housework. Notably, none of the five unemployed husbands in this sample did housework, which is understandable in their effort to find jobs. In developed countries, the notion of "househusband" was acknowledged and applied in some specific family groups in the studies of Musa (2014) and Kolpashnikova (2018). Even so, Vietnamese husbands have been resistant to this notion, especially ones living in rural areas. Increasing earnings reduces the wife's domestic-household time (Bittman et al., 2003; Gough \& Killewald, 2011). This adjustment, however, is minor, and the minimum limited threshold is set at three hours (Figure 2-Wife). Meanwhile, the husband's maximum ceiling is one hour, and the predicted line falls to zero hours if his earnings continue to rise (Figure 2-Husband). The gap between the wife's lower limited threshold and husband's upper limited threshold indicates that gender inequality in Vietnam is substantially worse than "the point of equality" in the research of Bittman et al. (2003) in Australia.

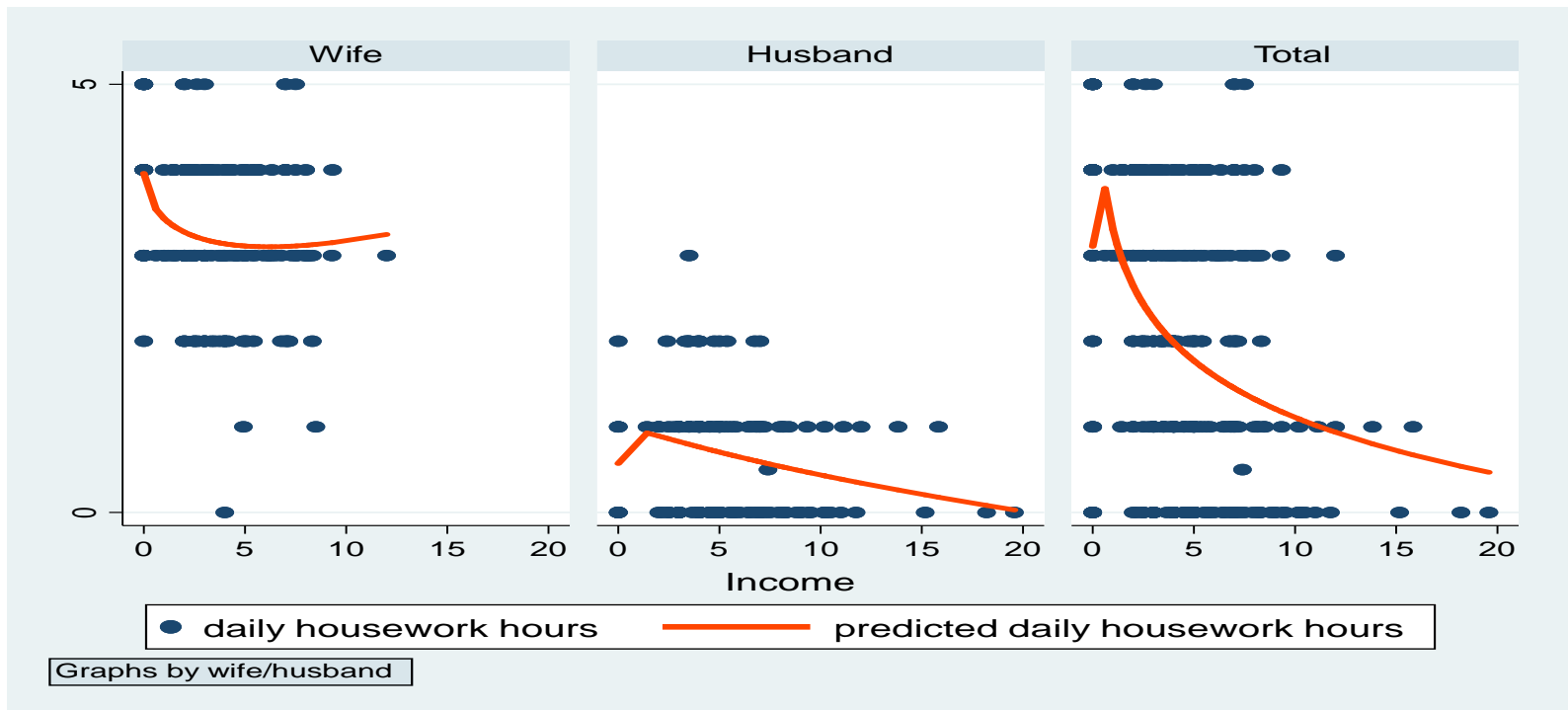

Figure 2. The predicted line relationship between income and housework by wife/husband.

The greater the contribution to the family income, the less time husband/wife has to do housekeeping (Figure 3-Total), but the shape of this relationship has a big difference between husband and wife. However, it does not imply a wife's household income share of more than 80 percent of family income, is concomitant with no household chores. The wife's trend line also reflects a downward adjustment, although it decreases from 4 hours/day to the 
lowest of 2.5 hours/day (Figure 3-Wife). In contrast, the husband's income share does not imply a reduction in time spent on housework; instead, they are likely to participate in domestic labor because they want to share it (Figure 3-Husband). The husband makes better use of his gender role than accepting an agreement to exchange income share and domestic labor.

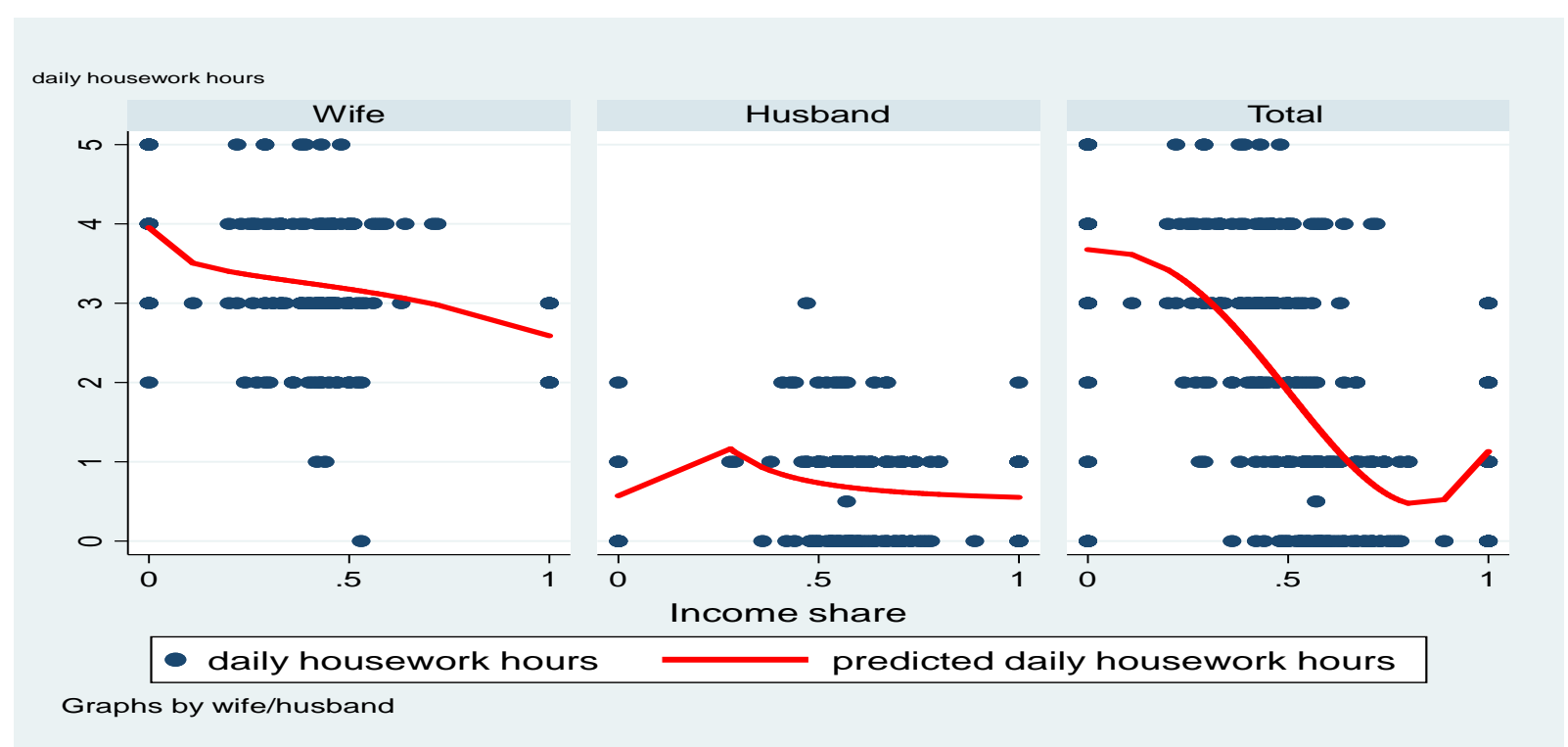

Figure 3. The predicted line relationship between income share and housework by wife/husband.



Figure 4. The predicted line relationship between income and daily childcare hours by wife/husband.

In common, the increment in spouse's income due to reduced time for childcare is shown in "total" in Figure 4. Parenting time is limited to a maximum of 2.4 hours and a minimum of 1.2 hours (Figure 4-Total). The first part of the "total" forecast line is explained by one part of the wife's forecast line because the wives with either zero or low income spend a substantial amount of time caring for children. The wife's trend line likewise varies somewhat from 2.5 hours to 1.8 hours. Meanwhile, the husband's trend line does not represent the inverse relationship between income and the number of hours spent on childcare, when the husband earns up to VND15 million, whose time is devoted more to taking care of children. The Korean father in Kim and Bang (2017) research and the Vietnamese father with high income seemingly do not trade daily childcare hours with their earnings. The predicted line between income share and daily childcare hours in all three parts of Figure 5 "wife", "husband" and "total" tends concomitantly an inverse U-shaped relationship, but is contrary to the U-shaped relationship of 
Killewald and Gough (2010). The predicted inverted-U lines in Figure 5 reflect the upward trend at the start of all three graphs, as income share increases until IS(wife)=0.2; IS(husband) $=0.4$, which compares to an increment in childcare hours, after the predicted line diminishes. The husband's income share does not change their childcare time much, but when the wife's income share increases from 0.2 , the childcare time downward adjusts from 2.3 hours to 1.4 hours. However, the lowest point of the wife's predicted line is still higher than the husband's highest point. In summary, income and income share have a greater effect on daily housework hours than on daily childcare hours.

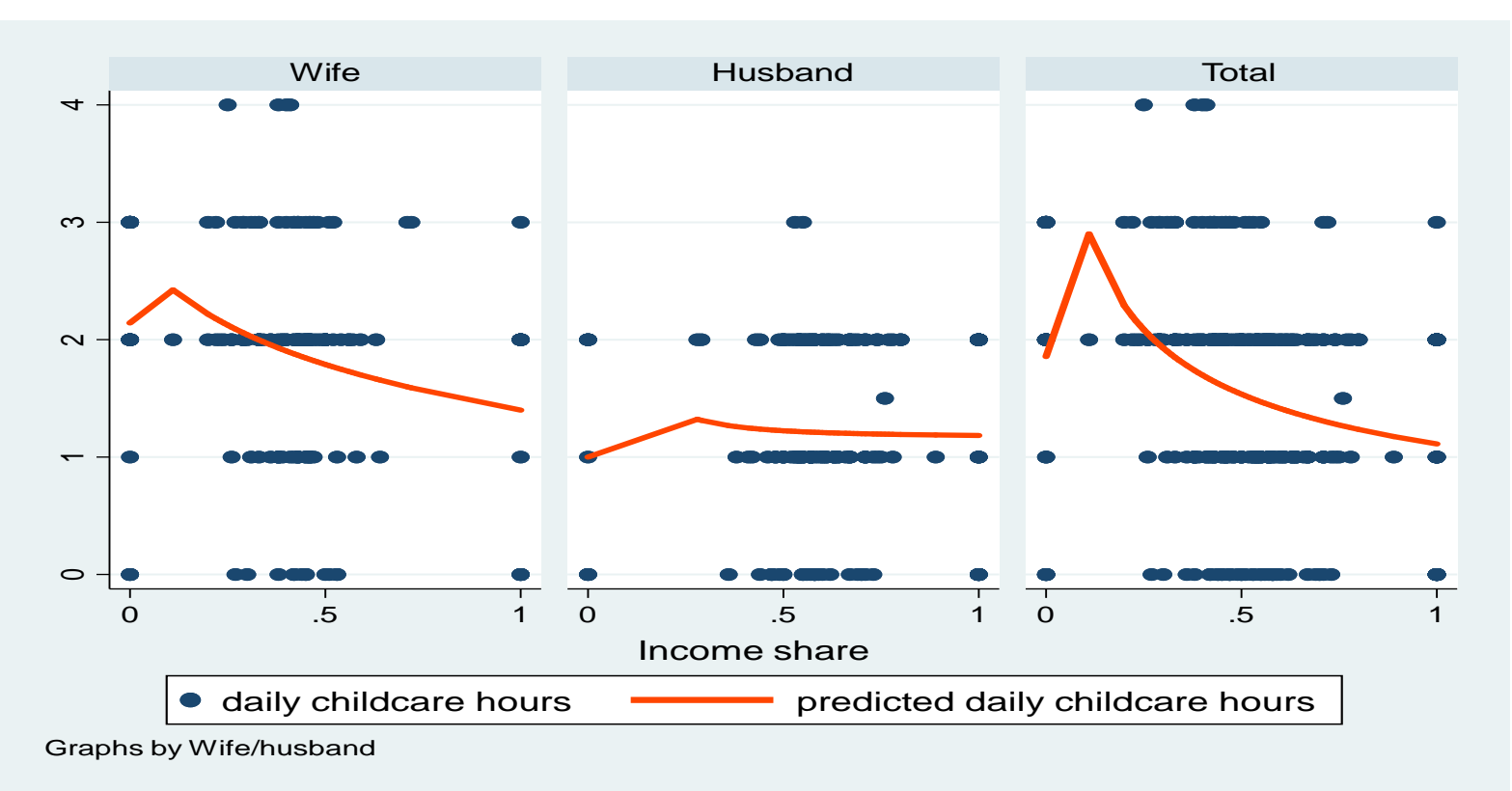

Figure 5. The predicted line relationship between income share and daily childcare hours by wife/husband.

Table 5. OLS regression - Factors affecting housework/childcare time.

\begin{tabular}{|c|c|c|}
\hline Independent variables & Housework & Childcare \\
\hline Wife/husband (WH) & & $-0.45 * * * *[0.115]$ \\
\hline Age & $-0.05 * * * *[0.011]$ & $-0.04^{* * * * *}[0.007$ \\
\hline Child characteristics (CC) & $0.21 * *[0.093]$ & $0.28 * * * *[0.063]$ \\
\hline \multicolumn{3}{|l|}{ 1. No child } \\
\hline 2. One child $<15$ years & $0.05[0.444]$ & $1.79 * * * *[0.286]$ \\
\hline 3. Two children $<15$ years & $0.619^{*}[0.351]$ & $2.10^{* * * * *}[0.226]$ \\
\hline 4 . One child $\geq 15$ years & $0.738 *[0.391]$ & $1.96 * * * *[0.252]$ \\
\hline 5.Two children or more $\geq 15$ years & $0.819^{*}[0.400]$ & $2.02 * * * *[0.258]$ \\
\hline Household size (HZ) & $-0.18^{* * *}[0.059]$ & $0.02 * * * *[0.03]$ \\
\hline Income (IC) & $-0.15^{* * * *}[0.073]$ & $-0.04^{*} *[0.019]$ \\
\hline $\mathrm{IC}=\mathrm{O}$ & & \\
\hline $\mathrm{O}<\mathrm{IC} \leq 3$ & $-1.55 * * * *[0.314]$ & $-0.24[0.205]$ \\
\hline 2. $3<\mathrm{IC} \leq 5$ & $-1.82 * * * * * 0.299]$ & $-0.05[0.199]$ \\
\hline $5<\mathrm{IC} \leq 7$ & $-1.89 * * * *[0.330]$ & $-0.26[0.218]$ \\
\hline 4. & $-2.14 * * * *[0.336]$ & $-0.44^{*}[0.222]$ \\
\hline Income share (IS) & $-0.54 * * * *[0.076]$ & $-0.02[0.055]$ \\
\hline O. $\quad \mathrm{IS}=\mathrm{O}$ & & \\
\hline $0<\mathrm{IS} \leq 0.3$ & $1.80^{* * * * *}[0.338]$ & $0.26[0.226]$ \\
\hline $0.3<\mathrm{IS} \leq 05$ & $1.41 * * * *[0.211]$ & $-0.17[0.146]$ \\
\hline $0.5<\mathrm{IS} \leq 0.7$ & $-0.01[0.220]$ & $-0.14[0.142]$ \\
\hline$\geq 0.7$ & & \\
\hline Cons & $5.80 * * * *[0.479]$ & $2.62 * * * *[0.328]$ \\
\hline No & 297 & 297 \\
\hline $\mathrm{R}^{2}$ & 0.395 & 0.20 \\
\hline
\end{tabular}




\subsection{Impact of Income on the Allocation of Household Chores by OLS Regression}

Based on the literature review, the study incorporates six factors affecting the two dependent variables: time spent in housework and childcare, into the model in Table 5. The independent variables include WH, AGE, CC, HZ, IC, IS, and CS. The correlation between WH and the amount of time spent on housework and childcare is 0.85 and 0.34, respectively. Since the variable WH has a high correlation with housework, proving that housework is a female-specified task, we exclude the variable WH from the model. The dichotomous variable -WH is statistically significant and has a considerable impact on the time spent in childcare and affirms that gender significantly influences the time spent in housework and less on time spent on children, which is in line with the conclusions in item 5.1 and the findings of Teerawichitchainan et al. (2010). Except for gender, based on a criterion of decreasing significance and importance, factors that affect daily housework hours are IS, IC, AGE, CC, HZ, and JC. The significant and essential factors are WH, CC, HZ, AGE, IC, JC, and IS that diminishingly influence childcare time. The variation in the order of the influencing factors reveals that (i) IS and IC have a substantial impact on housework time (ii) childcare time, on the other hand, is impacted firstly by household demographic variables, and is then influenced by IC and IS. This result is consistent with the conclusion of Knodel, Loi, Jayakody, and Huy (2005); Teerawichitchainan et al. (2010) demonstrating that changing the period time of the research 2005 to 2019 does not alter the view of the division of labor, especially when the subject of the research is a rural family.

Through these coefficients, IC and IS heavily impact daily housework hours and slightly impact daily childcare hours, and is consistent with the conclusion in section 5.1. Simultaneously, Table 5 shows that housework time reduces hierarchically by $-1.55 ;-1.82 ;-1.89 ;-2.14$ and is statistically significant when each income subgroup moves. Although the income affects the amount of time spent on childcare, the coefficient of this variable is several times

smaller $\left(\frac{0.45}{0.04}=11.25\right)$ compared to gender characteristics, arguing that caring for children is a gendered-specific task that is only partially affected by IC. Unlike the significant level of the IC subgroups, not all IS's subgroups have the same trend. Only two subgroups of IS are less than or equal to 0.5 of total household income and impact housework time are 1.80 and 1.41 , respectively. Significantly, the group $0.7<\mathrm{IS} \leq 1.0$ does not show the trend because single wives are responsible for most of the housework, and in contrast, the husband is responsible for relatively little housework. The $\mathrm{CC}$ significantly and positively affects both housework and childcare. These coefficients' CC's subgroups (0.05; 0.62; 0.74; 0.82) suggest that time spent in housework increases from hierarchical CC subgroups (Table 5). A household with older children and more children does not mean that it spends less time doing housework, contrary to the conclusion of Berk and Berk (1978) and the prediction in section 3-3 that adolescent and adult children share housework with their parents. Inversely, the bigger the household size, the less time the husband or wife spends doing housework. All stages of a child's growth need to be taken care of, but just various care approaches. The component coefficient of the subgroup $\mathrm{CC}$, in particular, is statistically significant $(\mathrm{p}<0.001)$. The time pattern dedicated to children has not made much difference since couples have a child. Couples with two children under 15 years old devote the most time to looking after their children compared to other subgroups, simultaneously, the time to care for children increases as the number of family member increase. Increasing age has a statistically significant reduction in housework and childcare, contrary to Shelton and John (1993) and Hersch and Stratton (1994).

\section{CONCLUSION AND ORIENTATIONAL SOLUTIONS FOR REDUCING INEQUALITY IN THE DOMESTIC LABOR DIVISION}

The findings of this study on the division of family labor did not demonstrate a more significant gender improvement than those of Teerawichitchainan et al. (2010); World Bank (2011) especially as this study was conducted in rural areas. Gender perspective has a profound impact on the division of household chores. As wives 
earn additional money, they spend less time on housework; nonetheless, the wives' and husbands' predicted trend changes are entirely different. In general, rising incomes reduce housework hours. Peculiarly, the exchange theory is not applied to unemployed husbands, and the more masculine they desire to appear, the less likely they are to participate in housework. The division of childcare is not the same as the division of housework. Through the Ttest, there is no assigned childcare for households with one child less than 15 years old. Nonetheless, the childcare assignment's households having two children or one child older than 15 years of age are statistically significant. Time devoted to childcare is statistically and significantly influenced by the following factors in descending order: HW, CC, HZ, AGE, IC and IS. Unlike the time devoted to housework, how much income contributes to the household does not affect childcare time. Nonetheless, income directly affects the daily childcare hours. The relationship between childcare hours and income share is in the form of "U-inverted", contrary to Killewald and Gough (2010). Although income is statistically significant to the time spent on childcare, the income effect is 11.25 times smaller than the gender effect. The family is the first social institution that can change the custom of genderassigned domestic labor. Parents' and grandparents' specific behaviors will positively influence the next generation's gender ideologies and opportunities. Gender equality successfully started in each family will be a solid foundation for establishing gender equality in all fields, regions, and specific rural areas. In contrast, the family is positioned within the community context, reflecting the promoting-incentives that institutions and policies have produced. The economy determines many opportunities for people to improve their living standards; hence policies and economic development substantially impact gender equality. Women need additional career opportunities to create income to achieve gender equality and reduce the imbalance of income in families. Traditional craft clubs improve rural economics, creating opportunities for women to split from families and earn money outside their families. It is necessary to step up training and vocational training, raise the qualifications for female employees. Gender propaganda should involve men to promote gender inequality progressively, and the mass media should play a role in gender equality.

Funding: This study received no specific financial support.

Competing Interests: The author declares that there are no conflicts of interests regarding the publication of this paper.

\section{REFERENCES}

Actionaid, V. (2008). Participatory poverty monitoring in rural communities in Vietnam Round 1. London: Oxfam.

Agarwal, B. (1997). "Bargaining"and gender relations: Within and beyond the household. Feminist Economics, 3(1), 1-51. Available at: https://doi.org/10.1080/135457097338799.

Ammons, S. K., \& Kelly, E. L. (2015). Work and family in the new economy. Bingley, UK: Emerald Group Publishing.

Baxter, J. (2002). 'Changes in the gender division of labour in Australia, 1986-1997', in T. Eardley and B. Bradbury, eds, Competing Visions: Refereed Proceedings of the National Social Policy Conference 2001, SPRC Report 1/02, Social Policy Research Centre (pp. 64-74). Sydney: University of New South Wales.

Baxter, J. (2018). Stay-at-home fathers in Australia (Research Report). Melbourne: Australian Institute of Family Studies.

Bélanger, D. (1998). Regional differences in household composition and family formation patterns in Vietnam. Journal of Comparative Family Studies, 31(2), 171-189. Available at: https://doi.org/10.3138/jcfs.31.2.171.

Berk, R. A., \& Berk, S. F. (1978). A simultaneous equation model for the division of household labor. Sociological Methods \& Research, 6(4), 431-468. Available at: https://doi.org/10.1177/004912417800600402.

Bianchi, S. M., Milkie, M. A., Sayer, L. C., \& Robinson, J. P. (2000). Is anyone doing the housework? Trends in the gender division of household labor. Social Forces, 79(1), 191-228. Available at: https://doi.org/10.1093/sf/79.1.191.

Bittman, M., England, P., Sayer, L., Folbre, N., \& Matheson, G. (2003). When does gender trump money? Bargaining and time in household work. American Journal of Sociology, 109(1), 186-2 14. Available at: https://doi.org/10.1086/378341. 
Bouffartigue, P. (2010). The gender division of paid and domestic work: Some remarks in favour of a temporal perspective. Time E' Society, 19(2), 220-238. Available at: https://doi.org/10.1177/096 1463x09337855.

Brown, H., \& Roberts, J. (2014). Gender role identity, breadwinner status and psychological well-being in the household. Sheffield Economics Research Paper No. (201400).

Coltrane, S. (2000). Research on household labor: Modeling and measuring the social embeddedness of routine family work. Journal of Marriage and Family, 62(4), 1208-1233. Available at: https://doi.org/10.1111/j.1741-3737.2000.01208.x.

Conceição, P. (2019). Human development report 2019: Beyond Income, beyond Averages, beyond today. New York, United Nations: United Nations Development Programme.

Cunningham, W., Alidadi, F., \& Buchhave, H. (2018). Vietnam's future jobs: The gender dimension: Vietnam's future jobs: The gender dimension (English). Vietnam: Ministry of Planning and Investment.

Demombynes, G., \& Testaverde, M. (2018). Employment structure and returns to skill in Vietnam: Estimates using the labor force survey. World Bank Policy Research Working Paper, No. (8364).

Desai, J. (2000). Vietnam through the lens of gender: Five years later. Food and Agriculture Organization of the United Nations Manuscript.

Dollar, D., Glewwe, P., \& Litvack, J. I. (1998). Household welfare and Vietnam's transition. Washington. US: World Bank Publications.

Evertsson, M. (2014). Gender ideology and the sharing of housework and child care in Sweden. Journal of Family Issues, 35(7), 927-949. Available at: https://doi.org/10.1177/0192513x14522239.

Geist, C., \& Cohen, P. N. (2011). Headed toward equality? Housework change in comparative perspective. Journal of Marriage and Family, 73(4), 832-844. Available at: https://doi.org/10.1111/j.1741-3737.2011.00850.x.

Gjerdingen, D. K., \& Center, B. A. (2005). First-time parents' postpartum changes in employment, childcare, and housework responsibilities. Social Science Research, 34(1), 103-1 16. Available at: https://doi.org/10.1016/j.ssresearch.2003.1 1.005.

Gough, M., \& Killewald, A. (2011). Unemployment in families: The case of housework. Journal of Marriage and Family, 73(5), 1085-1 100. Available at: https://doi.org/10.1111/j.1741-3737.2011.00867.x.

GSO. (2019). The Vietnam population and housing census o0:O0 hours on 1st April 2019. Ha Noi: UNFPA Viet the Statistic Publisher.

GSO \& UNFPA. (2005). Vietnam migration survey 2004: Major findings. Hanoi: Statistical Publishing House.

Hersch, J., \& Stratton, L. S. (1994). Housework, wages, and the division of housework time for employed spouses. The American Economic Review, 84(2), 120-125.

Institute for Social Development Studies. (2015). Social determinants of gender inequality in Vietnam: Findings of a research study between 2012-2015. Hanoi: Hong Duc Publising House.

James, K., \& Clay-Warner, J. (2015). The second shift and the nonstandard shift: How working nonstandard hours affects the relationship between the division of household labor and wives' fairness perceptions. In Work and Family in the New Economy. Bingley, UK: Emerald Group Publishing Limited.

Kan, M. Y., Sullivan, O., \& Gershuny, J. (2011). Gender convergence in domestic work: Discerning the effects of interactional and institutional barriers from large-scale data. Sociology, 45(2), 234-251. Available at: https://doi.org/10.1177/0038038510394014.

Kan, M.-Y., Hertog, E., \& Kolpashnikova, K. (2019). Housework share and fertility preference in four East Asian countries in 2006 and 2012. Demographic Research, 41, 1021-1046. Available at: https://doi.org/10.4054/demres.2019.41.35.

Kan, M.-Y., \& Laurie, H. (2018). Who is doing the housework in multicultural Britain? Sociology, 52(1), 55-74. Available at: https://doi.org/10.1177/0038038516674674.

Killewald, A., \& Gough, M. (2010). Money isn't everything: Wives' earnings and housework time. Social Science Research, 39(6), 987-1003. Available at: https://doi.org/10.1016/j.ssresearch.2010.08.005.

Kim, J.-S., \& Bang, H. (2017). Education fever: Korean parents' aspirations for their children's schooling and future career. Pedagogy, Culture \& Society, 25(2), 207-224. Available at: https://doi.org/10.1080/14681366.2016.1252419. 
Knodel, J., Loi, V. M., Jayakody, R., \& Huy, V. T. (2005). Gender roles in the family: Change and stability in Vietnam. Asian Population Studies, 1(1), 69-92. Available at: https://doi.org/10.1080/17441730500125888.

Kolpashnikova, K. (2018). American househusbands: New time use evidence of gender display, 2003-2016. Social Indicators Research, 140(3), 1259-1277. Available at: https://doi.org/10.1007/s11205-017-1813-z.

Lynellyn, D. L., Le, N. H., Allison, T., Le, T. P. M., \& Nguyen, A. D. (2000). Changing gender relations in Vietnam's post Doi Moi Era. Policy Research Report on Gender and Development, Working Paper Series No. 14.

Makiko, F., \& Philip, N. (2007). Housework and social policy. Social Science Research, 36(2), 512-530. Available at: https://doi.org/10.1016/j.ssresearch.2006.04.005.

Moghadam, V. M. (1995). Economic reforms, women's employment, and social policies case studies of China, Viet Nam, Egypt, and Cuba. Helsinki. Finland: UNU-WIDER.

Musa, C. N. (2014). The challenges of the "husband wife" phenomenon in family and marital unequal relationships. Journal of Educational and Social Research, 4(3), 297. Available at: https://doi.org/10.5901/jesr.2014.v4n3p297.

Nguyen, C. V., Van den Berg, M., \& Lensink, R. (2011). The impact of work and non-work migration on household welfare, poverty and inequality: New evidence from Vietnam. Economics of Transition, 19(4), 771-799. Available at: https://doi.org/10.1111/j.1468-0351.2011.00416.x.

Quyen, D. H., Nguyen, T. L., Nguyen, V. D., Nguyen, M. T., \& Do, T. H. (2006). A survey on roles of women in agriculture and rural development in Nghia Hiep Communes, Yen My District, Hung Yen Province. Vietnam Journal of Agricultural Sciences, 4(5), 273-280.

Ruppanner, L., Bernhardt, E., \& Brandén, M. (2017). Division of housework and his and her view of housework fairness: A typology of Swedish couples. Demographic Research, 36, 501-524. Available at: https://doi.org/10.4054/demres.2017.36.16.

Shelton, B. A., \& John, D. (1993). Does marital status make a difference? Housework among married and cohabiting men and women. Journal of Family Issues, 14(3), 401-420. Available at: https://doi.org/10.1177/019251393014003004.

St-Amour, N., Laverdure, J., Devault, A., Manseau, S., \& Jacob, R. (2007). The difficulty of balancing work and family life: Impact on the physical and mental health of Quebec families. Quebec: National Institute of Public Health.

Statista. (2021). Vietnam: Unemployment rate from 1999 to 2020 . Retrieved from: https://www.statista.com/statistics/444617/unemployment-rate-in-vietnam/. [Accessed July 20, 2021 ]

SUR, A. (2016). The 2015 national internal migration survey: Major findings. Ha Noi: Vietnam News Agency Publishing House.

Teerawichitchainan, B., Knodel, J., Loi, V. M., \& Huy, V. T. (2010). The gender division of household labor in Vietnam: Cohort trends and regional variations. Journal of Comparative Family Studies, 41(1), 57-85. Available at: https://doi.org/10.3138/jcfs.41.1.57.

Truong, D., Giao, N., Ly, L., \& Giang, N. (2020). Family migration decisions of rural households in Vietnam. Management Science Letters, 1O(13), 2945-2950. Available at: https://doi.org/10.5267/j.msl.2020.5.031.

UNDP. (2019). Inequalities in human development in the 21 st century: Viet nam briefing note. Human development report 2019. Vietnam. United Retrieved from: https://www 1.undp.org/content/dam/vietnam/docs/others/Viet\%20Nam\%20Briefing\%20note.pdf.

Van der Lippe, T., Treas, J., \& Norbutas, L. (2018). Unemployment and the division of housework in Europe. Work, Employment and Society, 32(4), 650-669. Available at: https://doi.org/10.1177/0950017017690495.

World Bank. (2006). Vietnam-country gender assessment. Washington, D.C. US: World Bank.

World Bank. (2011). Vietnam-country gender assessment. Ha Noi: Vietnam Country Office.

Views and opinions expressed in this article are the views and opinions of the author(s), Asian Development Policy Review shall not be responsible or answerable for any loss, damage or liability etc. caused in relation to/arising out of the use of the content. 